\title{
石炭灰にアルマイトスラッジを複合化させた放電プラズマ焼結体の機械的性質
}

\section{Mechanical Property of Composite Material using Coal Fly Ash and Alumite Sludge by Spark Plasma Sintering}

\author{
学○菊池 晴信 (琉大院・工) \\ 正 神田 康行 (琉大·工)
}

Harunobu KIKUCHI, University of the Ryukyus, Yasuyuki KANDA, University of the Ryukyus,
正 福本 功 (琉大・工)

Isao FUKUMOTO, University of the Ryukyus,

Key Words ; Alumite sludge, Coal Fly Ash, Spark Plasma Sintering,

\section{1. 緒言}

火力発電の際に発生する石炭灰、アルミニウムの表面皮膜 処理の過程で発生するアルマイトスラッジ（以降スラッジと 称する）は、現在、産業廃衰物として処理されており、有効 な活用方法が模索されている。筆者らはこれまでに、石炭灰 の有效な活用方法として、粘土と複合化させた焼結体を作製 している ${ }^{(1)}$ 。本研究では石炭灰とスラッジの有効利用を目的 とし、両者を複合化させた焼結体を作製し、その際の配合 比・焼成温度などの条件を変化させることにより、機械的性 質が高まる最適条件について検討する。

\section{2. 実験材料と実験装置}

実験材料として、スラッジは、生材のベーマイトを電気炉 を用いて、空気中にて $1573 \mathrm{~K}$ で二時間の熱処理をし、 $\alpha$ アル ミナスラッジ $\left(\alpha-\mathrm{Al}_{2} \mathrm{O}_{3}\right)$ としたものを用いた。石炭灰は、集 塵装置で集められた粒度の細かいフライアッシュをそのま ま用いた。各実験材料の化学組成を Table 1、Table 2 に示す。 両者の混合は乳鉢にて行った。焼結装置として、電気炉（超 高速昇温電気炉 SB-1415C、モトヤマ社）および放電プラズ マ焼結装置（SPS : Spark Plasma Sintering、住友石炭鉱業、ド クターシンターシリーズ 2050)）を用いた。

本実験の焼成条件として、電気炉の場合は焼成温度を $1573 \mathrm{~K} \sim 1773 \mathrm{~K}$ と変化させ、昇温時間は 2 時間、保持時間は 2 時間と固定し、石炭灰とスラッジの配合比が $2: 1 、 1: 1$ の試験 片を作製した。SPS の場合は、焼成温度は $1573 \mathrm{~K}$ 、昇温時間 を 30 分、保持時間を 5 分、加圧力を $20 \mathrm{MPa}$ と固定し、石炭 灰とスラッジの配合比が $1: 1 、 1: 2 、 1: 3$ の試験片を作製した。 なおSPSにおいても、配合比 $2: 1$ の焼成を試みたが、試料が 溶融したため試験片が作製できなかった。

機械的性質を評価するために、光学顕微鏡による試験片断 面の観察、ビッカース硬さ試験、三点曲げ試験より曲げ強さ および曲げ弾性係数を測定した。

\section{3. 実験結果と考察 \\ 3.1 電気炉の場合}

Fig.2 に焼成温度と曲げ弾性係数の関係を示す。1573K で は $2 \mathrm{GPa}$ であったが、1673K および $1773 \mathrm{~K}$ での平均值は約 9GPa であった。Fig.3 に焼成温度と曲げ強さの関係を示す。

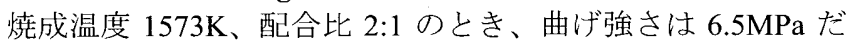
ったが、燒成温度の上昇と共に曲げ強さも大きくなり、1673K では約 4 倍、1773K では約 10 倍となった。配合比 1:1におい ても、同様な傾向にあった。

これらの結果より、1573K では試料が十分焼結していない ことが読み取れる。また、スラッジの割合が高いもの(1:2、

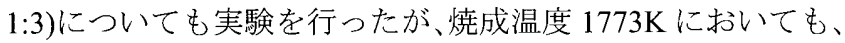
曲げ強さは約 $2.5 \mathrm{GPa}$ と低い值だった。これは、焼成温度が 試料の焼結温度に達していなかったためと考えられる。これ より、スラッジの増加により焼結温度が高くなることが推察 される。なお、1:1よりも2:1の方が曲げ強さが大きかった。

Fig.4 に光学顕微鏡による試験片の断面写真を示す。Fig.4 の矢印を付した黒い部分は空孔であると考えられる。空孔の 少ない $1773 \mathrm{~K} の 2: 1$ は機械的性質、主に曲げ強さが高いのに 対し、空孔の多い1773K の 1:1、1673K の 2:1 は、曲げ強さ

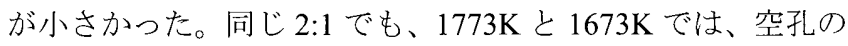

Table 1 Chemical composition of Coal Fly Ash

\begin{tabular}{|l|l|l|l|l|c|l|c|c|}
\hline $\mathrm{SiO}_{2}$ & $\mathrm{Al}_{2} \mathrm{O}_{3}$ & $\mathrm{Fe}_{2} \mathrm{O}_{3}$ & $\mathrm{TiO}_{2}$ & $\mathrm{CaO}$ & $\mathrm{MgO}$ & $\mathrm{Na}_{2} \mathrm{O}$ & $\mathrm{K}_{2} \mathrm{O}$ & $\mathrm{MnO}$ \\
\hline 62.4 & 23.5 & 3.3 & 1.43 & 0.75 & 0.51 & 0.35 & 0.61 & 0.02 \\
\hline \multicolumn{10}{c|}{ (mass\%) }
\end{tabular}

Table 2 Chemical composition of Alumite Sludge

\begin{tabular}{|l|l|l|l|l|l|}
\hline $\mathrm{SiO}_{2}$ & $\mathrm{Al}_{2} \mathrm{O}_{3}$ & $\mathrm{Fe}_{2} \mathrm{O}_{3}$ & $\mathrm{CaO}$ & $\mathrm{MgO}$ & $\mathrm{Na}_{2} \mathrm{O}$ \\
\hline 0.99 & 91.2 & 0.3 & 0.02 & 0.21 & 0.72 \\
\hline
\end{tabular}

Load

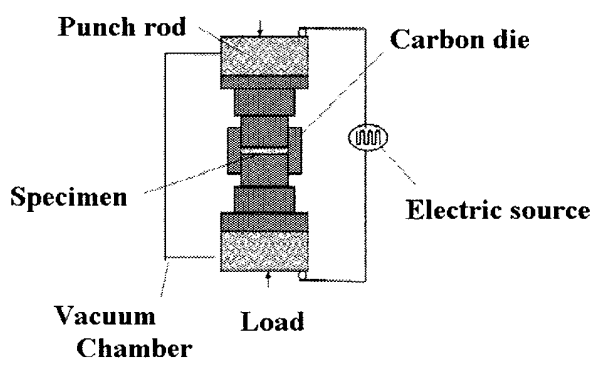

Fig.1 Outline drawing of SPS

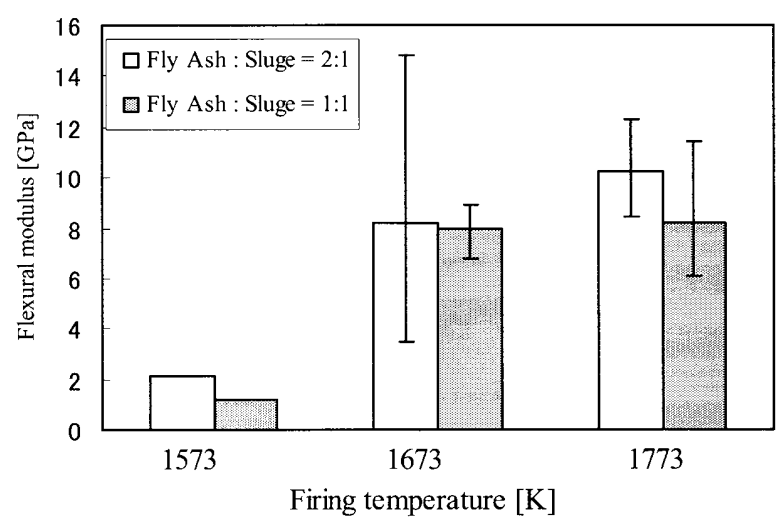

Fig.2 Relationship between firing temperature and flexural modulus

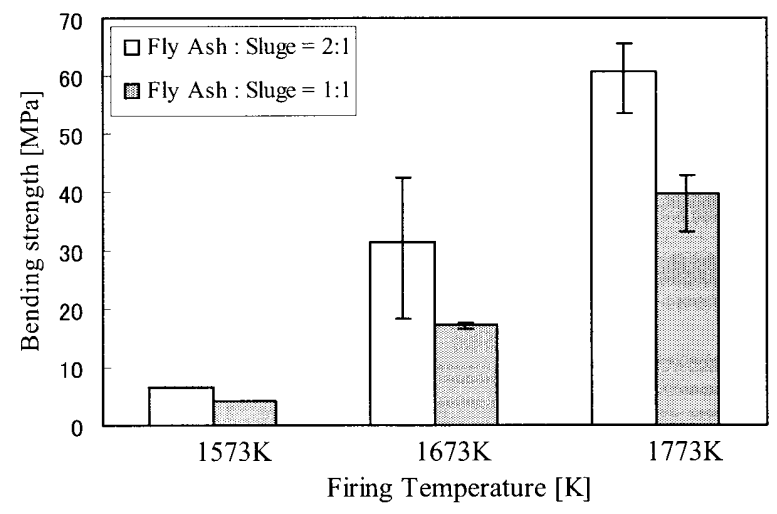

Fig.3 Relationship between firing temperature and Bending strength 
大きさや粗密に差異が見て取れるが、これは溶融あるいは軟 化した石炭灰が空孔を埋めたものと考えられる。

\subsection{SPS の場合}

Fig.5 に各配合比による試験片のビッカース硬さを示す。ス ラッジの配合比が大きくなるにつれて硬くなっていることか ら、スラッジは硬さに影響を及ぼしていると考えられる。な お硬さのばらつきは、1:1 が最も大きく、1:2 は小さかった。

Fig.6に曲げ弾性係数と配合比の関係を示す。曲げ弾性係数 は 1:2 が最も大きく $57.0 \mathrm{GPa}$ を示した。1:1 $1: 3$ 共に平均值 は45.6GPa であったが、1:1 はばらつきが大きかった。

Fig.7に曲げ強さと配合比の関係を示す。曲げ強さの平均值

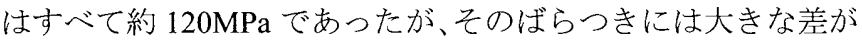
見られ、1:1と $1: 2$ ばらつきが大きく、1:3 は小さかった。

Fig.8 に光学影微鏡による試験片の断面写真を示す。電気炉 で焼成した試験片と同じく、矢印を付した写真の黑い部分は 空孔であると考えられる。SPS の試験片は電気炉の試験片と 比べ、空孔が少なく、曲げ強さが大きかった。その中でもさ らに空孔の少ない 1:3 は、曲げ強さのばらつきが少なかった。 これに対し、空孔の多い1:1、1:2 はばらつきが大きかった。

以上より、電気炉と SPS より作製した焼結体の機械的性質 を比較すると、曲げ弾性係数は SPS が電気炉の 4 倍以上、曲 げ強さは 1.5 倍以上の值であり、いずれもSPSによる試験片 が高い値を示していた。電気炉は石炭灰の配合比の多いもの が曲げ強さが強かった。逆に SPS ではスラッジの多いものが、 曲げ強さおよび曲げ弾性係数のばらつきが少なかった。顕微 鏡写真を比べると、電気炉は空孔が多かったが、SPS では少 なかった。

\section{4. 結言}

本研究では、石炭灰とスラッジを複合させ、電気炉および 放電プラズマ焼結法により複合材料を作製した結果、以下の ことが明らかとなった。

(1)電気炬による焼結では、石炭灰:スラッジ=2:1、1773K の焼 結体が、最も曲げ強さが高く、かつ、ばらつきが少なかっ た。顕微鏡で試験片の断面を観察した結果、作製した焼結 体はすべて空孔が多かった。また、スラッジの増加により 焼結温度が高くなることがわかった。

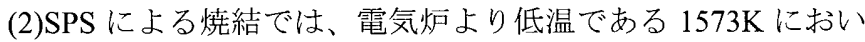
ても、スラッジの配合比の大きい試料の焼結が可能であり、 1:3のものが、曲げ強さ、曲げ弾性係数共に高く、ばらつき も少なかった。

(3)電気炉と SPS より作製した焼結体の機械的性質を比較する と、いずれの場合もSPS による試験片が高い值を示してい た。電気炉の場合は石炭灰の多いものが強く、SPS の場合 はスラッジの多いものが、機械的性質のばらつきが少なか った。顕微鏡による断面写真では、電気炉は空孔が多かっ たが、SPS では少なかった。

\section{参考文献}

(1) Fukumoto, I., and Kanda, Y., Mechanical Properties of Composite Material Using Coal Ash and Clay, Journal of Solid Mechanics and Materials Engineering, Vol.3, No.5, (2009), pp.739-747

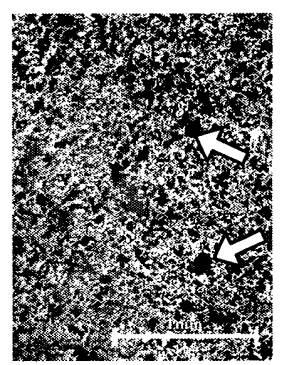

$2: 1$

$1673 \mathrm{~K}$

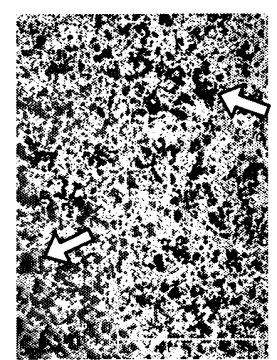

$2: 1$

$1773 \mathrm{~K}$

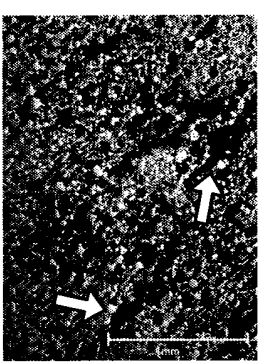

$1: 1$

$1773 \mathrm{~K}$
Fig.4 Microphotograph of cross section of specimen fabricated by electric furnace

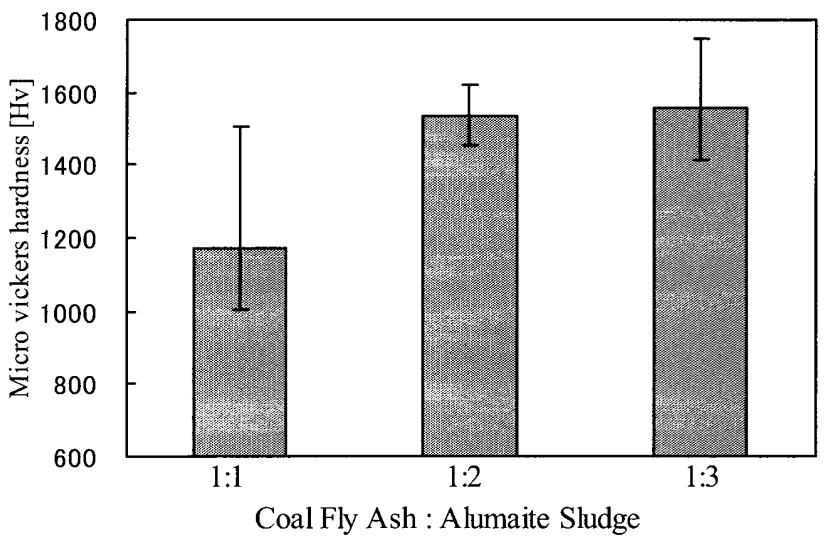

Fig.5 Relationship between Vickers hardness and blending ratio

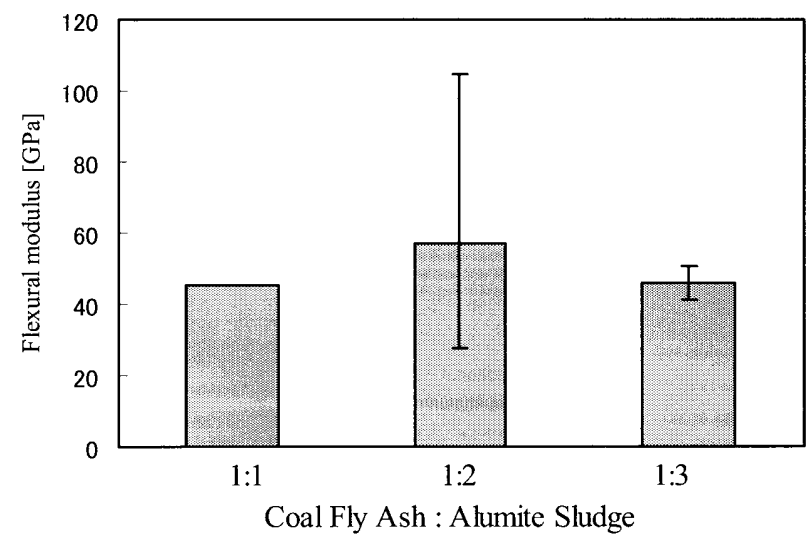

Fig.6 Relationship between flexural modulus and blending ratio

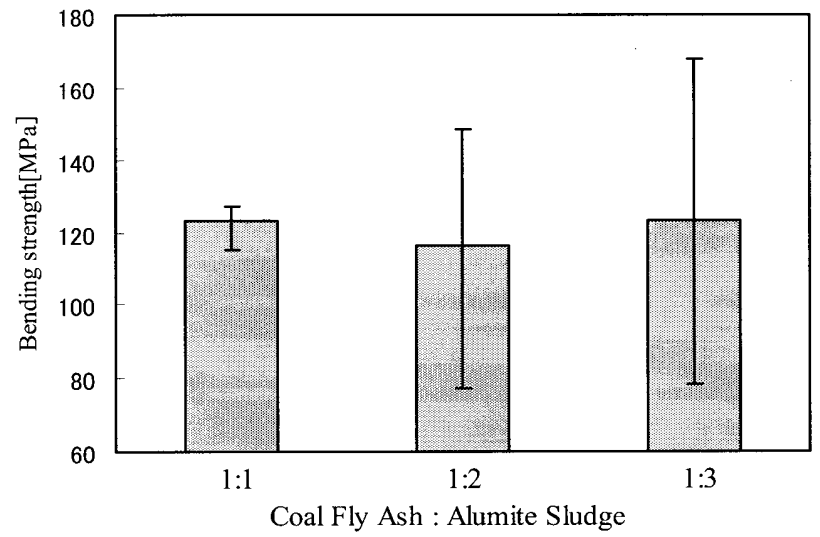

Fig.7 Relationship between bending strenght and blending ratio

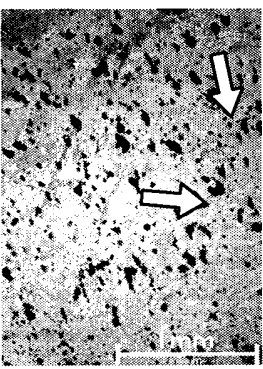

$1: 1$

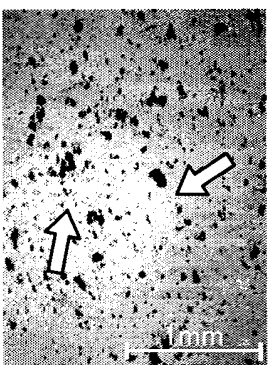

$1: 2$

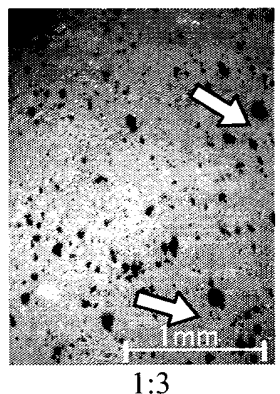

$1: 3$
Fig. 8 Microphotograph of cross section of specimen fabricated by SPS 